\title{
Comprehensive Income Reporting and Earnings Management
}

\author{
Runita Arum Kanti ${ }^{1^{*}}$ \\ ${ }^{1}$ Padjadjaran University, Bandung, Indonesia
}

\begin{abstract}
Purpose. This paper aims to identify the association between comprehensive income reporting and earnings management. More specifically, this study examines whether the implementation of comprehensive income reporting regulations, namely SFAS 130 and ASU 2011-05 is associated with a decrease in earnings management.

Design/ methodology. Data for all variables is retrieved from Compustat Global for a nine-year sample of 7962 US firms reporting under International Financial Reporting Standards (IFRS) that provide all the necessary data to conduct the study. The Modified Jones Model is used as a proxy to measure earnings management. Comprehensive income figures are retrieved from Compustat. Recalculated (as-if) numbers are used for firm years prior to the implementation of SFAS 130. While as-reported amounts are used for the years where SFAS 130 has been implemented and also the years during the implementation of ASU 2011-05.

Findings. Comprehensive income is found to be significantly negatively associated with earnings management through discretionary accruals. Furthermore, the interaction effects indicate that, after the implementation of SFAS 130 and ASU 2011-05, comprehensive income becomesmore negatively associated with discretionary accruals.

Relevance. Other than contributing to the growing literature regarding the usefulness of comprehensive income reporting, this research has implications for the FASB in assessing whether they achieved the target of better comprehensive income reporting.
\end{abstract}

Key words: Comprehensive Income, Earnings management, Interaction effect, Reporting Regulations, SFAS 130, ASU 2011-05.

\section{INTRODUCTION}

In June 1997, the US Financial Accounting Standards Board (FASB) released Statement of Financial Accounting Standard (SFAS 130) which requires comprehensive income and components of comprehensive income be reported in a prominent financialstatement. The issuance of SFAS 130 was partly in response to users groups, namely the Association for Investment Management and Research (AIMR), requesting for clearer Comprehensive Income reporting. The seemingly arbitrary manner in which items were included or excluded from the income statement and the lack of transparency were the main points of the AIMR's concerns.Under SFAS 130, effective for all financial statements reported after December 15, 1997, several items that were previously reported as direct 
adjustments to equity are to be reported as adjustments to net income to arrive at comprehensive income.

The implementation of SFAS 130 was mainly done to increase the transparency of Comprehensive Income disclosure. SFAS 130 allows firms to choose between three formats of reporting, two of which in the statement of performance using either the one statement approach or the two statement approach. The third format allows comprehensive income to be reported in the statement of stockholders' equity. The majority of firms chose the latter though it is considered to be the least transparent reporting format. As a response, the FASB later issued Accounting Standards Update (ASU) 2011-05 which no longer allows the reporting of comprehensive income in the statement of stockholders' equity.

This research aims to address the relation of more transparent CI reporting and earnings management using the archival approach. A similar study was conducted byLobo \& Zhou(2001) for firms in Shanghai with results stating that the extent of earnings management is negatively related to corporate disclosure quality.

Prior research generally reports that more transparent disclosures lead to better detection of earnings management (Hirst \& Hopkins, 1998and Hunton, et al., 2006). Regarding earnings management practices in general,it is likely that managers have an incentive to achieve certain targets and therefore use earnings management opportunistically. This may be especially true when compensation mechanisms based on earnings are enforced. Earnings management can occur when managers exercise their discretion over firms accounting numbers with or without restrictions. Evidenceof earnings management indicates opportunistic application of managers' reporting discretion.(Watts \& Zimmerman, 1990; Fields et al., 2001).Earnings management can take the form of maximizing earnings in a given period, smoothing earnings over time, avoiding losses or earnings declines. (Fields, et al., 2001)

This study contributes to the ongoing debate regardingusefulness of comprehensiveincome disclosure, specifically through its ability to predict earnings management. This study differs from prior research in that it uses a sample range comparing three periods, namely comprehensive income reporting prior to the implementation of SFAS 130, during SFAS 130 implementation, and after the implementation of ASU 2011-5. The results of this study can be useful in examining whether the FASB were indeed correct in implementing their regulations, and achieved the target of better comprehensive income reporting.

\section{LITERATURE REVIEW}

\subsection{Comprehensive Income Reporting}

Comprehensive income is defined as the change in equity of a business enterprise during a period from transactions and other events and circumstances from non-owner sources. In SFAS 130, FASB introduced the term "other comprehensive income" (OCI) to better reflect certain revenues, expenses, gains, and losses - elements of comprehensive income that are excluded from net income. Comprehensive income is a broader measure of earnings since it consists of net 
income plus OCI. According to Eaton et al, the following four items are the components of OCI most frequently reported in a firms' comprehensive income:

1. Foreign currency translation adjustments.

2. Adjustments for pension liability

3. Adjustments for unrealized holding gains/losses on marketable securities

4. Certain gains/losses on derivative instruments which are designated and qualify as cash flow hedges.

SFAS 130 regulates that all items that are required to be recognized under accounting standards as components of comprehensive income be reported in a financial statement that is displayed with the same prominence as other financial statements. It allows three alternative reporting formats: Components of other comprehensive income and total comprehensive income may be reported below the total for net income in a statement that reports results of operations, in a separate statement of comprehensive income that begins with net income, and in a statement of stockholders' equity. Prior to SFAS 130, firms were not obliged to report comprehensive income nor its components anywhere in the financial statements.

On June 2011, FASB issued ASU 2011-05, which eliminates the option of presenting OCI in the statement of stockholders' equity and limits companies to two choices, both of which require a link to net income. This was done because the majority of firms avoided presentation on the income statement and statement of comprehensive income and instead chose the less transparent display in the statement of stockholders' equity (Hunton, et al., 2006). Prior research indicates that users are less likely to detect earnings management when relevant information is reported in the statement of stockholders' equity (e.g., Hirst and Hopkins 1998; Hirst, et al., 2004).

\subsection{Disclosure Transparency and Comprehensive Income Reporting}

As previously stated, the implementation of SFAS 130 was a response to the AIMR's request for a more transparent reporting of comprehensive income. The FASB suggests firms report CI in the performance statement since it is deemed to be more prominent, and hence more transparent than the statement of stockholders' equity(Hunton, et al., 2006)

The statement of stockholders' equity holds large amounts of nonperformance related information that may result in information regarding comprehensive income being overlooked or being difficult to extract. Prior research by Brown (1997)states that financial analysts regards the stockholders' equity as the least useful component of an annual report. When issuing SFAS 130, the FASB failed to consider the limitations of allowing CI reporting in the statement of stockholders' equity.

Hirst and Hopkins (1998) define transparent financial disclosures as those from which needed information can be more easily extracted and more effectively used to understand a firms business condition. They conclude that a higher level of transparency is achieved when OCI and comprehensive income is displayed in a statement of comprehensive income compared to in a statement of stockholders' equity.A similar research regarding financial reporting transparency and earnings management was conducted by Hunton et al (2006). It shows that participants in 
the more transparent condition suggest that earnings management will be obvious to readers, harmful to stock prices, and damaging to reporting reputations.

These two prior researches indicate that there is indeed a correlation between comprehensive incomereporting and transparency.Both these researches suggest that reporting CI through the statements of stockolders' equity will not provide the same level of transparency compared to the two other permitted formats. The FASB responded through the issuance of ASU 2011-05 by no longer allowing reporting of CI in the statement of stockholders' equity. Taken together with the results of prior studies, the changes in regulations imply an increase in transparency of comprehensive income reporting.

\subsection{Disclosure Transparency and Earnings Management}

Hirst et al (2004) noted that managers often choose to implement less transparent reporting formats. When surveyed by the FASB on their exposure draft, 90 percent of managers supported disclosure of CI in the statement of stockholders' equity. In actuality, managers also regularly choose the less transparent reporting format that is allowed by standards. For example, the majority of firms opt to display CI in the statement of stockholders' equity, report cash flow under the indirect method, and disclose employee stock option compensation expense in the notes (Hunton, et al., 2006). This provides evidence that managers believe that there are certain benefits to choosing a lower level of disclosure transparency.

A lower level of disclosure together with asymmetric information makes it possible for managers to manage earnings(Schipper, 1989). Reversely, it can be inferred that disclosure increases transparency and reduces incentives to manage earnings because greater transparency help stakeholders to more easily detect earnings management.

Archival research regarding impacts of comprehensive income disclosure on earnings management has previously been conducted by Lin \& Rong(2012). The findings suggest disclosure of other comprehensive income can restrain earnings management to some extent in order to provide better information regarding firms' performance.

Another relevant archival research related to earnings management wasLee, et al's(2006) study of the first time comprehensive income reporting decisions of publicly traded property-liability insurers. The study conducted indicates that firms identified as earnings managers are more likely to select the less transparent disclosure, it does not address whether the more transparent reporting format would better predict earnings management. All these prior findings suggest that reporting standards that improve transparency would facilitate an easier detection of earnings management and reduce the practice of earnings management itself.

\subsection{Hypothesis Development}

Managers have various incentives to manage earnings, for example to meet analysts' forecast, to achieve stable performance, to increase the manager's job security, etc(Hunton, et al., 2006 and Hirst \& Hopkins, 1998). The detection of earnings management itself can be difficult if stakeholders cannot comprehend information provided by a firm, or worse, if information is not disclosed at all. 
The higher the quality of information disclosure is, the lower the degree of information asymmetry and the easier it would be to detect earnings management. While a lower quality of information disclosure indicates a higher degree of information asymmetry, hencea higher likelihoodof earnings management. An alternative way of stating this is that shareholders of firms that have more informative disclosure policies can more easily detect earnings management; therefore, management is less likely to engage in such behavior. Based on the above inference, this study proposes the following hypothesis:

$\mathrm{H} 1$. There is a negative association between comprehensive income reporting and earnings management.

More specifically, this study aims to identify whether the implementation of SFAS 130 and ASU 2011-5 regarding comprehensive income reporting has managed to provide more transparent disclosure and hence is associated with a decraese in earnings management.Hirst and Hopkins (1998) define transparent financial disclosures as those from which needed information can be more easily extracted and more effectively used to understand a firms business condition. Prior toSFAS 130, information regarding comprehensive income and its components were scattered and as aresult was difficult to assess. A number of comprehensive income components could be estimated from other financial statements. However, deriving other comprehensive income from those numbers required a great understanding of accounting(Chambers, et al., 2006). Taking the above information into account, this research anticipates the following:

H2. Transparency of comprehensive income reporting will increase in the period post-SFAS 130, as a result earnings management will decrease.

Prior research suggests that disclosure in the statement of stockholders' equity is less transparent compared to disclosure in the income statement (Hirst and Hopkins 1998; Brown 1997) The FASB encouraged firms to disclose comprehensive income using the more transparent one-statement or two-statement approach. Yet the majority of firm chose to implement CI reporting in thestatement of stockholders' equity(Chambers, et al., 2006). On June 15, 2011, the FASB issued ASU 2011-05, requiring companies to report comprehensive income and its components either at the bottom of the statement of comprehensive income, or in its own statement immediately following the income statement. As a result of this disclosure regulation amendment, this study predicts the following:

H3. Transparency of comprehensive income reporting will increase in the period post-ASU 2011-5, as a result earnings management will decrease.

\section{RESEARCH METHODOLOGY}

\subsection{Sample selection}

In the pre-SFAS 130 periods, firms have not fully disclosed comprehensive income and its components in a prominent financial statement. Hence, comprehensive income will be recalculated using required Compustat data. The sample used for the pre-SFAS 130 period consists of all 1995-1997 firm years that have the required Compustat data required to recalculate $\mathrm{CI}$. 
For the post-SFAS 130 periods, sample data will be taken from Compustat for firm year 2008-2011. For the post-ASU 2011-05 periods, Compustat data from firm year 2012-2013 will be used. In total, the sample period spans for nine years, namely three years before mandatory disclosure, three years after the implementation of SFAS 130 and two years after the implementation of ASU 20115. The years prior to mandatory disclosures use recalculated comprehensive income numbers, while the post SFAS 130 firms years use as-reported comprehensive income amounts.

I exclude financialservices firms' because their accrual processes differ considerably from the Modified Jonesmodel. Similarly, natural gas is a regulated industry whose accruals also follow a differentprocess and is excluded.

The initial Compustat dataset for the years stated in Figure 1 consisted of 90532 firm-year observations. After eliminating firm-year duplicates and eliminating missing values, winsorization at the $1 \%$ level was done in order to eliminate extreme values for both the dependant and independent variables. The total sample consists of 7962 companies with 29948 firm-year observations. A graphical illustration of the development of the final sample is provided in Figure 1.

\begin{tabular}{|c|c|}
\hline Initial Sample & • 90532 firm year observations \\
\hline Filtering & $\begin{array}{c}\cdot \text { Eliminate duplicate records } \\
\cdot \text { Exclude missing values } \\
\text { • Exclude Financial Services (2 digit SIC } \\
\text { Code 60-67) and Natural Gas Industry } \\
\text { (2 digit SIC Code 13) } \\
\text {-Winsorize dependent and independent } \\
\text { variables at } 1 \% \\
\end{array}$ \\
\hline Final Sample & $\begin{array}{c}\cdot \text {.7962 firms } \\
\text { •29948 firm year observations }\end{array}$ \\
\hline
\end{tabular}

Figure 1 Final Sample Derivation

\subsection{Regression model}

A way of enganging in earnings management isthrough increasing or decreasing income by creating accruals; these are often referred to as nondiscretionary accruals. However, it is the discretionary accruals, accruals that are made with the purpose of shifting earnings between reporting periods that are of concern. These types of accruals include using increasing or decreasing estimates of bad debt reserves, warranty costs, and inventory write-downs.(Fang Li, et al., 2010)

Several different models can be used to measure discretionary accruals. This study estimate discretionary accruals ("DACC") as the difference between total accruals ("TACC") and non-discretionary accruals ("NDACC"). To estimate nondiscretionary accruals, the Modified Jones model will be used. This model has been shown to be the most powerful model for detecting earnings management 
(Dechow, et al., 1995). Subramanyan (1996) suggests that discretionary accruals are viewed by market participants as a less reliable component of earnings, which implies that discretionary accruals are more likely to be subject to managers' manipulation and, therefore, are valid measures of earnings management.

Collins \& Hribar(1999) suggest the cash flow method as a means of calculating total accruals. Under this method, total accruals are measured as follows:

$$
\mathrm{TACC}_{\mathrm{t}}=\mathrm{EBXT}_{\mathrm{t}}-\mathrm{OCF}_{\mathrm{t}}
$$

Where:

EBXT $_{t}=$ Earnings before extraordinary items and discontinued operations for period $\mathrm{t}$; and

$\mathrm{OCF}_{\mathrm{t}}=$ Change in current liabilities during period $\mathrm{t}$.

I calculate discretionary accruals ("DACC") as the difference between total accruals ("TACC") and non-discretionary accruals ("NDACC"). The Modified Jones Model used to calculate non-discretionary accruals is formulated as follows:

$$
\mathrm{NDACCt}=\alpha 1(1 / \text { At }-1)+\alpha 2(\triangle \mathrm{REVt}-\Delta \mathrm{RECt})+\alpha 3(\mathrm{PPEt})
$$

Where:

$\triangle \mathrm{REVt}=$ Revenues in year $\mathrm{t}$ less revenues in year $\mathrm{t}-1$ scaled by total assets at $\mathrm{t}-$ 1.

$\Delta \mathrm{RECt}=\mathrm{Net}$ receivables in year $\mathrm{t}$ less net receivables in year $\mathrm{t}-1$ scaled by total assets at $\mathrm{t}-1$.

PPEt = Gross property plant and equipment in year $\mathrm{t}$ scaled by total assets at $\mathrm{t}$ 1 ; and

Estimates of $\alpha 1, \alpha 2$, and $\alpha 3$ are obtained using the ordinary least squares estimation of the following equation:

$$
\mathrm{TACCt}=\alpha 1(1 / \mathrm{At}-1)+\alpha 2(\Delta \mathrm{REVt})+\alpha 3(\mathrm{PPEt})+\varepsilon \mathrm{t}
$$

Where TACCt is total accruals scaled by lagged total assets.

Lastly, discretionary accruals are as:

$$
\mathrm{DACCt}=\mathrm{TACCt}-\mathrm{NDACCt}
$$

Based on the defined variables, the following regression model isestablished toexamine the factors affecting earnings management:

$\mathrm{H} 1 \quad: \mathrm{DACCt} \mid=\beta 0+\beta 1 \mathrm{CI}+\beta 2 \mathrm{ROA}+\beta 3 \mathrm{lev}+\beta 4$ firmsize $+\beta 5 \mathrm{BTM}+\varepsilon 0 \quad$ (5): $\mathrm{H} 2 \& \mathrm{H} 3:|\mathrm{DACCt}|=\beta 0+\beta 1 \mathrm{CI}+\beta 2 \mathrm{D} 1+\beta 3 \mathrm{D} 2+\beta 4(\mathrm{D} 1 * \mathrm{CI})+\beta 5(\mathrm{D} 2 * \mathrm{CI})+\beta 6 \mathrm{ROA}$ $+\beta 7$ lev $+\beta 8$ firmsize $+\beta 9 \mathrm{BTM}+\varepsilon 0$

Where:

$|\mathrm{DACC} t|=$ Absolute value of discretionary accruals

CI = Comprehensive Income

D1 = Dummy variable with the value of 1 for pre SFAS 130 period

D2 = Dummy variable with the value of 1 during SFAS 130 period

This study runs the regression model using dummy variables for three different time spans, namely before the implementation of SFAS 130, during SFAS 130 implementation, and during ASU 2011-05 implementation.

Since firms were not obligated to report comprehensive income numbers before fiscal year 1998, I did a recalculation of comprehensive income for sample years 1995-1997. The as-ifcalculation is done by adding the three SFAS 130 
components to net income (Compustat $\# 172+\Delta \# 238+\Delta \# 230+0.65$ times $\Delta[\# 29$ \#298]) the same method of recalculation was done in Chambers, et al., 2006 and Dhaliwal, et al., 1999. The three SFAS 130 components are: adjustments for unrealized gains and losses on available-for-sale marketable securities (SEC), foreign currency translations (FCT) and minimum required pension liabilities (PEN). I will not examine separately the fourth SFAS 130 component, certain gains/losses on derivative instruments which are designated and qualify as cash flow hedges, as it is not separately identified in Compustat.

\subsubsection{Control Variables}

To specifically identify the association betweencomprehensive income reportingandearnings management, it is necessary to control for other variables that may compromise the accuracy of the research.Lobo \& Zhou(2006)report that larger firms may be more inclinedto manage their earnings because the complexityof their operations makes it difficult for users todetect overstatement.This study controls for firm size by using the natural logarithmof total assets (LnASSETS).

Leverage will be included as higher leverage implies higherrisk and riskier firms are more likely to manage earnings(Fung \& Goodwin, 2013). This study computes the LEV variable as the book value oftotal liabilities divided by the book value of total assets using year end numbers.

The extent of earnings management as measured by discretionary accruals is related to firm performance in that managers save income through negative discretionary accruals when current performance is good (DeFond \& Park, 1997). Also a study conducted by Dechow, et al., (1995)imply that a failure to control for firm may lead to erroneousinferences.Return on total assets is used as a proxy for firm performance calculated as EBIT scales by total assets at the beginning of the fiscal year.

Lastly, (Larcker \& Richardson, 2004)controls for the book-to-market (BTM) ratiowhen measuring discretionary accruals using the modifiedJones model in order to mitigate measurement errorassociated with the discretionary accruals. This ratio controlsfor expected growth in operations where certain firms with higher expected growth might have a higher tendancy to manage earnings.

\section{RESULTS}

\subsection{Correlation Statistics}

Table 2 presents correlations between the dependent, independent, and control variables. Correlation indicates the direction (either positive or negative) and the strength of a relationshipbetween two coefficients. Consistent with my hypothesis, earnings management (dacc) is significantly negatively related to comprehensive income (citotal). The output showing a negative relation between comprehensive income and earnings management implies that with increasing levels of comprehensive income firms manage earnings decreasingly. All other variables are also significantly negatively correlated to earnings management. This relation opposes the expectation that increasing levels of earnings management are associated with increasinglevels of ROA, BTM, firm size, and leverage. 
To conclude, all variables are significantly correlated at the 5\% level. The levels of correlation are not high enough to cause bias in the research conducted. Hence, there are no correlations within the sample that will significantly compromisethe reliability of the regression outcomes.Issues of multicollinearity do not appear to have a significant impact on the outcome of the regression analyses.

Table 1 Spearman Correlation Statistics

\begin{tabular}{|c|c|c|c|c|c|c|}
\hline $\begin{array}{l}\text { Variable } \\
(\mathrm{N}=29948)\end{array}$ & Dacc & citotal & ROA & BTM & firmsize & Leverage \\
\hline dacc & 1.0000 & & & & & \\
\hline citotal & $\begin{array}{l}-0.2664 \\
(0.0000)\end{array}$ & 1.0000 & & & & \\
\hline ROA & $\begin{array}{l}-0.1278 \\
(0.0000)\end{array}$ & $\begin{array}{l}0.6589 \\
(0.0000)\end{array}$ & 1.0000 & & & \\
\hline BTM & $\begin{array}{l}-0.0476 \\
(0.0000)\end{array}$ & $\begin{array}{l}-0.1292 \\
(0.0000)\end{array}$ & $\begin{array}{l}-0.2226 \\
(0.0000)\end{array}$ & 1.0000 & & \\
\hline firmsize & $\begin{array}{l}-0.3180 \\
(0.0000)\end{array}$ & $\begin{array}{l}0.5889 \\
(0.0000)\end{array}$ & $\begin{array}{l}0.3382 \\
(0.0000)\end{array}$ & $\begin{array}{l}-0.0229 \\
(0.0001)\end{array}$ & 1.0000 & \\
\hline leverage & $\begin{array}{l}-0.0542 \\
(0.0000)\end{array}$ & $\begin{array}{l}0.0432 \\
(0.0000)\end{array}$ & $\begin{array}{l}-0.0246 \\
(0.0000)\end{array}$ & $\begin{array}{l}-0.1679 \\
(0.0000)\end{array}$ & $\begin{array}{l}0.3197 \\
(0.0000)\end{array}$ & 1.0000 \\
\hline
\end{tabular}

* Figures in brackets are p-values

To analyze the differences between average discretionary accruals in the three periods I conduct a T-test of the means of DACC between periods with results as follows: 
Table 2 Two Sample T-test 1

Period 1 (Pre-SFAS) and Period 2 (SFAS 130)

\begin{tabular}{lcrrr}
\hline \multicolumn{1}{c}{ Group } & Obs & Mean & Std. Err. & Std. Dev. \\
\hline Period 1 (Pre-SFAS) & 12800 & 0.077414 & 0.000678 & 0.076669 \\
Period 2 (during SFAS) & 11665 & 0.062184 & 0.000606 & 0.065412 \\
combined & 24465 & 0.070152 & 0.00046 & 0.071925 \\
diff & & 0.01523 & 0.000916 & \\
\hline diff = mean(0) - mean(1) & & $\mathrm{t}=16.6349$
\end{tabular}

Ho: $\operatorname{diff}=0$

degrees of freedom $=24463$

Ha: diff $<0$

$\operatorname{Pr}(\mathrm{T}<\mathrm{t})=1.0000$
Ha: diff $!=0$

$\operatorname{Pr}(|\mathrm{T}|>|\mathrm{t}|)=0.0000$
Ha: diff $>0$

$$
\operatorname{Pr}(\mathrm{T}>\mathrm{t})=0.0000
$$

When comparing the means of DACC for two periods, before and after the implementation of SFAS 130, I conclude that the mean is decreasing from the latest to the most recent period. This serves as an indication that earnings management (discretionary accruals) decreases following the implementation of SFAS 130. For thet-tests conducted, the difference is statistically significant as shown by the Pvalue of 0.0000 for the right hand tail test. This implies that the implementation of SFAS 130 effectively decreases earnings management.

Table 3 Two Sample T-test 2

Period 2 (SFAS 130) and Period 3 (ASU 2011-05)

\begin{tabular}{|c|c|c|c|c|c|}
\hline \multicolumn{2}{|l|}{ Group } & Obs & Mean & Std. Err. & Std. Dev. \\
\hline \multicolumn{2}{|c|}{ Period 2 (during SFAS 130) } & 11665 & 0.062184 & 0.000606 & 0.065412 \\
\hline \multicolumn{2}{|l|}{ Period 2 (ASU 2011-5) } & 5483 & 0.055651 & 0.000815 & 0.060348 \\
\hline \multicolumn{2}{|l|}{ combined } & 17148 & 0.060095 & 0.000488 & 0.063908 \\
\hline \multicolumn{3}{|l|}{ Diff } & 0.006533 & 0.001045 & \\
\hline \multicolumn{3}{|c|}{$\operatorname{diff}=\operatorname{mean}(1)-\operatorname{mean}(2)$} & \multicolumn{2}{|c|}{$\mathrm{t}=6.2501$} & \\
\hline \multicolumn{2}{|l|}{ Ho: $\operatorname{diff}=0$} & \multicolumn{3}{|c|}{ degrees of freedom $=17146$} & \\
\hline Ha: $\operatorname{diff}<0$ & \multicolumn{2}{|c|}{ Ha: diff $!=0$} & \multicolumn{2}{|c|}{ Ha: diff $>0$} & \\
\hline $\operatorname{Pr}(\mathrm{T}<\mathrm{t})=1.0000$ & \multicolumn{3}{|c|}{$\operatorname{Pr}(|\mathrm{T}|>|\mathrm{t}|)=0.0000$} & $>\mathrm{t})=0.0000$ & \\
\hline
\end{tabular}


Furthermore, I also conduct a t-test for the period during SFAS 130 and after the amendment. Again, the mean of discretionary accruals decreases from the former period to the latter. For the t-tests conducted, the difference is statistically significant as shown by the P-value of 0.0000 for the right hand tail test. Overall, the results could indicate that the implementation of SFAS 130 and its amendment leads to a decrease in a firms' discretionary accruals level. Hence, a regression analysis is necessary to further analyze this notion.

\subsection{Regression analysis}

\subsubsection{Fixed Effects Regression Results}

To assess the robustness of the previous results, I run the regression analysis using fixed effects which assume that certainspecific characteristics within the individual data may impact or bias the dependent variable, hence a need to control for this. Fixed effects remove the effect of those time invariant characteristics in order to derive the net effect of the predictors on the dependent variable.

Another assumption under the fixed effects model is that each entity is different therefore the entity's error term and the constant should not be correlated with the others. If the error terms are correlated, then the random effects model is more appropriate.I run a Hausman test for both regression models to decide whether fixed effects or random effects should be in place. The null hypothesis is that the preferred model is random effects versus the alternative fixed effects. When testing for both hypothesis, theP-value obtained is 0.00000 thus $\mathrm{H} 0$ is rejected. The results of this testing concludes that in order to answer the first hypothesis I should indeed control for firmfixed effects (see appendix I for Hausman Test results). The results for the regression analysis can be seen in the table below:

Table 4 Fixed Effects Regression of Model 1

\begin{tabular}{|c|c|c|c|c|}
\hline \multicolumn{2}{|l|}{ Fixed-effects (within) regression } & \multirow{2}{*}{$\begin{array}{l}\text { Number of } \\
\text { obs } \\
\text { Number of } \\
\text { groups }\end{array}$} & \multirow{2}{*}{$\begin{array}{l}= \\
=\end{array}$} & \multirow{2}{*}{$\begin{array}{r}29948 \\
7962\end{array}$} \\
\hline Group variable: gvkey (Firm) & & & & \\
\hline R-sq: within $=0.0184$ & & $\begin{array}{l}\text { Obs per } \\
\text { group: min }\end{array}$ & $=$ & 1 \\
\hline between $=0.1631$ & & avg & $=$ & 3.8 \\
\hline overall $=0.1079$ & & $\max$ & $=$ & 9 \\
\hline & & $\mathrm{F}(5,20981)$ & $=$ & 82.25 \\
\hline $\operatorname{corr}\left(\mathrm{u} \_\mathrm{i}, \mathrm{Xb}\right)=0.0412$ & & Prob $>\mathrm{F}$ & $=$ & 0 \\
\hline Dacc & Coef. & Std. Err. & $\mathbf{T}$ & $\mathbf{P}>\mathbf{t}$ \\
\hline \multicolumn{5}{|l|}{ Independant Variable } \\
\hline Citotal & -0.00001 & 0.0000 & -2.9100 & 0.0040 \\
\hline \multicolumn{5}{|l|}{$\underline{\text { Control Variables }}$} \\
\hline ROA & -0.0019 & 0.0042 & -0.4500 & 0.6560 \\
\hline
\end{tabular}




\begin{tabular}{|c|c|c|c|c|}
\hline Leverage & 0.0407 & 0.0034 & $\begin{array}{c}11.9900 \\
-\end{array}$ & 0.0000 \\
\hline Firmsize & -0.0101 & 0.0007 & 14.5700 & 0.0000 \\
\hline BTM & -0.0005 & 0.0012 & -0.4100 & 0.6840 \\
\hline _cons & 0.1066 & 0.0041 & 25.8100 & 0.0000 \\
\hline $\begin{array}{l}\mathrm{F}(7961,21981)=2.00 \\
* \text { significant at } 1 \% \text { level }\end{array}$ & & $\begin{array}{l}\text { rob }>F= \\
.0000\end{array}$ & & \\
\hline
\end{tabular}

Based on the results of the above regression, 'citotal', the variable of interest in this study, has a significantly negative correlation with earnings management (dacc). Though the coefficient obtained is nearly zero, this result is in line with the first hypothesis stating that there is a negative association between comprehensive income reporting and earnings management. It is in contrary to what was found under the OLS regression which showed a positive correlation between the two variables.

The majority of the control variables also yield results that are as previously predicted. ROA, firm size and BTM all indicate negative relations to earnings management, although the relation is only significant for firm size. There is an unexpected observation between discretionary accruals and leverage, as is was expected that highly leveraged firms would be more likely to engage in earnings management (DeFond \& Jiambalvo, 1994). Although there are interesting outcomes of the regression, the main effect of comprehensive income towards earnings management is proven to be significant.

To assess the association between the implementation of certain regulations and earnings management, I run the fixed effects regression again using interactions between the dummy variables specified to indicate the different time periods. Table 5 exhibits the results of the regression.

Table 5 Fixed Effects Regression of Model 2

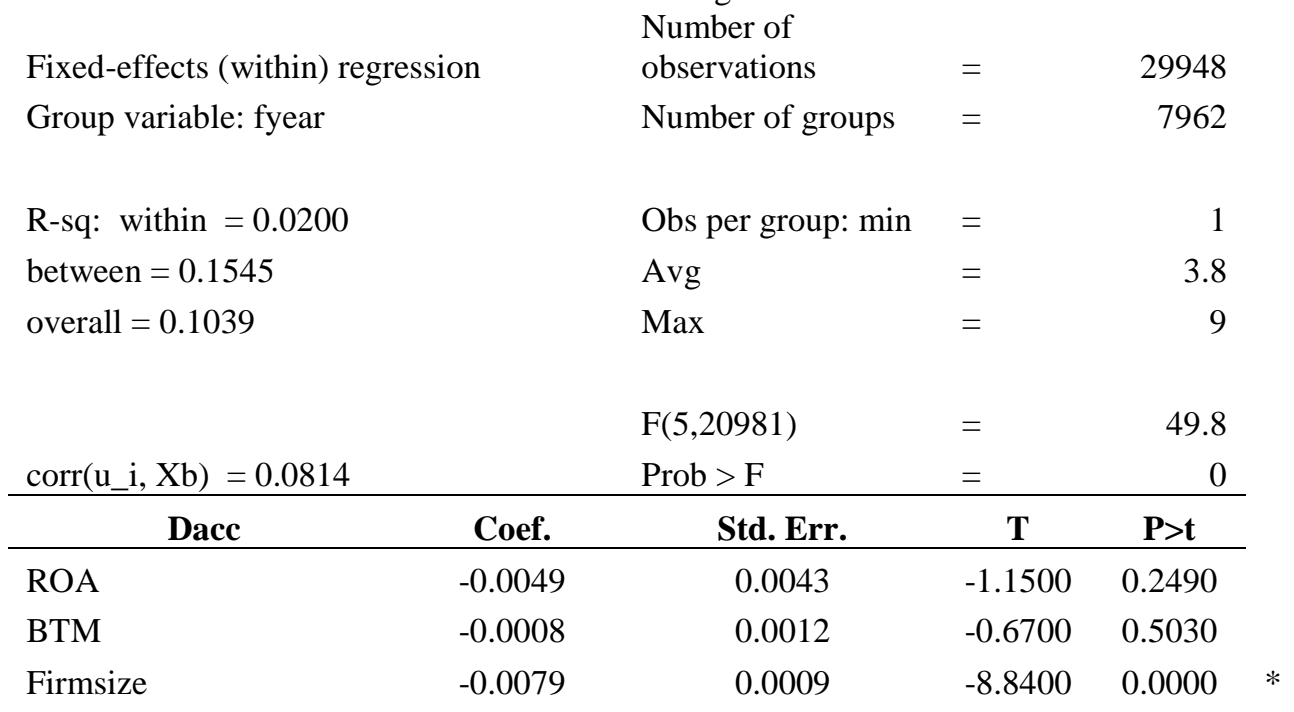




\begin{tabular}{lccccc} 
Leverage & 0.0411 & 0.0034 & 12.0900 & 0.0000 & $*$ \\
D1 & 0.0095 & 0.0018 & 5.1700 & 0.0000 & $*$ \\
D2 & 0.0056 & 0.0011 & 4.9600 & 0.0000 & $*$ \\
Citotal & -0.000002 & 0.0000 & -0.5700 & 0.5660 & \\
D1\#citotal & -0.00001 & 0.0000 & -2.8300 & 0.0050 & $*$ \\
D2\#citotal & -0.000005 & 0.0000 & -1.9000 & 0.0570 & $* * *$ \\
cons & 0.0880 & 0.0059 & 14.8600 & 0.0000 \\
\hline
\end{tabular}

$\mathrm{F}(7961,21977)=2.00$

Prob $>\mathrm{F}=0.0000$

* significant at $1 \%$ level

$* * *$ significant $10 \%$ level

The regression results reveal that there is a negative association between comprehensive income and discretionary accruals, although the results are statistically insignificant.The coefficient for D1 is significantly positive, indicating that average discretionary accruals is higher for the Pre-SFAS 130 period compared to the other two periods. A significantly positive coefficient is also obtained for D2, indicating that average discretionary accruals is higher for period 2 (during the implementation of SFAS 130) compared to the other two periods. Thus, the base period (in this case the period after implementation of amendment ASU 2011-05) has a lower average discretionary accrual level compared to the other two periods.

The interaction between comprehensive income and D1 (Pre-SFAS 130) is significant at the $1 \%$ level. The coefficient amounting to -0.00001 decreases the marginal effect of comprehensive income to earnings management compared to other periods. As a result of the change in marginal effect of dummy variable 1 (PreSFAS 130) the slope of the model changes from -0.000002 to -0.000015 (derived from $\beta 1+\beta 4$ ). This result is in line with the second hypothesis stating that transparency of comprehensive income reporting will increase in the period postSFAS 130, as a result earnings management will decrease.

Unlike the insignificant result obtained under the OLS regression, the interaction between comprehensive income and D2 (the period when SFAS 130 was implemented) is negatively significant at the $10 \%$ level. This indicates that there is a negative change in the marginal effect of comprehensive income on discretionary accruals. As a result of the change in marginal effect of dummy variable 2 (SFAS 130) the slope of the model changes from -0.000002 to -0.00002 (derived from $\beta 1+\beta 4+\beta 5$ ).In conclusion, the results provide support for the hypothesis that there is negative correlation between comprehensive income and earnings management in the period after the implementation of ASU 2011-05.

\section{DISCUSSION}

\subsection{Summary}

The statistically significant relationship between comprehensive income and discretionary accruals suggests that thereis an association between the two variables.Under the fixed effects model the findings indicate a negative association. The first hypothesis stating that as comprehensive income increases, earnings 
management will decrease is only proven to be true under the fixed effects model. It is worth noting that since I am using panel data, the assumption underlying the fixed effects model seem more appropriate for the research in place.

The second regression model is set up to identify whether the implementation of SFAS 130 and ASU 2011-05 regarding comprehensive income reporting manages to provide more transparent disclosure and hence is associated with a decrease in earnings management.A univariate analysis conducted comparing the mean of discretionary accruals between the three periods shows a declining trend in average discretionary accruals. Thisserves as a first indication that after the implementation of comprehensive income reporting regulations, managers are engaging in less earnings management.

Furthermore, the main effects of the the dummy variable D1 (Pre-SFAS 130) and D2 (during implementation of SFAS 130) for both D1 and D2 are significantly positive, indicating that average discretionary accruals is higher for the Pre-SFAS 130 period compared to the other two period and also indicating that average discretionary accruals is higher for period 2 (during the implementation of SFAS 130) compared to the other two periods.

The interaction between D1 and comprehensive and the interaction between D2 and comprehensive income are both significant under the fixed effects model. The negative interaction coefficient indicates that there is a decrease in marginal effect of comprehensive income on discretionary accruals after the implementation of SFAS-130. This is in line with the second hypothesis stating that transparency of comprehensive income reporting will increase in the period post-SFAS 130, as a result earnings management will decrease.

The same results occurfor the interaction between D2 and comprehensive income. This indicates that the third hypothesis stating that transparency of comprehensive income reporting will increase in the period post-ASU 2011-5 hence earnings management will decrease is also valid. The model as a whole indicates that there is an inverse relationship between comprehensive income and earnings management. Furthermore, the marginal effect from period one to two and two to three become increasingly negative. This highlights the finding that the comprehensive income reporting regulations and its amendment is effective in improving the level of earnings management.

\subsection{Conclusion}

This research set out to analyze the association between the implementation of certain comprehensive income reporting regulations and earnings management through discretionary accruals. The aim of both SFAS 130 and ASU 2011-05 was to increase transparency and ultimatelyimprove firms' reporting of comprehensive income.Furthermore, this research contributes by providing evidence regarding whether the Financial Accounting Standards Board (FASB) successfully met their goal.

The results show a consistent significant association between comprehensive income and discretionary accruals.Under the fixed effects model, a negative association occurs, indicating that firms with higher levels of comprehensive income engage in less earnings management. This supports the notion that more 
transparent comprehensive income reporting is associated witha decrease in earnings management.

Furthermore, the results comparing the marginal effects of the three periods (Before any regulations were in place, after the implementation of SFAS 130, and after the implementation of ASU 201105) indicate that there is significant decreasing effects of discretionary accruals after the implementation of SFAS 130 and also after the implementation of ASU 2011-05. In conclusion, the FASB are seemingly heading in the right direction with the implementation of the comprehensive income reporting regulations. However,care should be taken when making practical recommendations based on these resultsas there are other factors/limitations that should be taken into consideration

First, it is important to emphasize that currently no model to detect earningsmanagement is considered perfect. Prior research indicates that The Modified Jones model is considered to be the most reliable. While this research only uses one proxy for earnings management, other proxiesor multiple earnings management proxies could be used in future research.

Second, not all data retrieved from Compustat were able to be included in this study. As explained in previous sections, only around one-third of the initial sample had all necessary data in order to proceed with the regression analysis. Also, financial service industries and natural gas companies were not included due to their highly regulated nature. This may have impacted the results considering the former engages in numerous transactions that are related to other comprehensive income adjustments.Lastly, this study uses as-if recalculated numbers to derive comprehensive income for the years prior to the mandatory implementation of SFAS 130 (1995-1997). An ideal regression would compare actual reported figures of comprehensive income. Unfortunately, such a regression is not feasible since only a small numbers of firms reported comprehensive income pre-SFAS 130. Nevertheless, this study should provide a sufficient baseline for future studies regarding comprehensive income reporting and earnings management.

\section{References}

Baginski, S., Conrad, E., \& Kimbrough, M. (2002). The Effect of Legal Environment on Voluntary Disclosure: Evidence From Management Earnings Forecasts Issued in U.S. and Canadian Markets. The Accounting Review, 77, 557-582.

Biddle, G. C., \& Choi, J.-H. (2006). Is Comprehensive Income Useful. Journal of Contemporary Accounting \& Economics, 2(1), 1-32.

Brown, P., (1997). Financial Data and Decision Making by Sell-side Analysts. The Journal of Financial Statement Analysis, 2, 43-48.

Chambers, D., Linsmeier, T., Shakespeare, C., \& Sougiannis, T. (2006). An Evaluation of SFAS No.130 Comprehensive Income Disclosure. Review of Accounting Studies, 12(4), 557-593.

Chen, T., (2011). Analysis on Accrual-Based Models in Detecting Earnings Management. Lingnan Journal of Banking, Finance and Economics, 2(1). 
Collins, D., \& Hribar, P. (1999). Errors in Estimating Accruals; Implications For Empirical Research. Working Paper: University of Iowa.

Dechow, M., Sloan, R., \& Sweeney, A. (1995). Detecting Earnings Management. The Accounting Review, 70(2), 193-225.

DeFond, M., \& Jiambalvo, J. (1994). Debt Covenant Violation and Manipulation of Accruals. Journal of Accounting and Economics, 17, 145-176.

DeFond, M., \& Park, C. (1997). Smoothing Income in Anticipation of Future Earnings. Journal of Accounting and Economics, 23, 115-130.

Dhaliwal, D., Subramanyam, K., \& Trezevant, R. (1999). Is Comprehensive Income Superior To Net Income As a Measure of Firm Performance. Journal of Accounting and Economic, 26, 43-67.

Fang Li, S., McDowell, E., \& Moore, E. (2010). Accrual Based Earnings Management, Real Transactions Manipulations and Expectations Management. s.l:Rider University.

Fields, T., Lys, T., \& Vincent, L. (2001). Empirical Research on Accounting Choice. Journal of Acconting \& Economics, 31, 255-307.

Frankel, R. M., Johnson, M. F., \& Nelson, K. K. (2002). The Relation Between Auditors' Fees For Nonaudit Services and Earnings Management. The Accounting Review , 77, 71-105.

Fung, Y., \& Goodwin, J. (2013). Short-term Debt Maturity, Monitoring and Accruals-Based. Journal of Contemporary Accounting and Economics, 9, 67-82.

Hirst, D., Hopkins, P., \& Wahlen, J. (2004). Fair Values, Income Measurement, and Bank Analysts' Risk. The Accounting Review.

Hirst, E., \& Hopkins, P. (1998). Comprehensive Income Reporting and Analysts' Valuation Judgements. Journal of Accounting Research, 36.

Hunton, J., Libby, R., \& Mazza, C. (2006). Financial Reporting Transparency and Earnings Management. The Accounting Review, 81(1), 135-157.

Lang, M. \& Lundhlom, R. (1993). Cross-Sectional Determinants of Analyst Ratings of Corporate Disclosures. Journal of Accounting Research, 31, 246271.

Larcker, F., \& Richardson, S. (2004). Fees Paid to Audit Firms, Accrual Choices, and Corporate Governance. Journal of Accounting Research, 42.

Lee, Y., Petroni, K., \& Shen, M. (2006). Cherry Picking, Disclosure Quality, and Comprehensive Income Reporting Choices: The Case of Property-Liability Insurers. Contemporary Accounting Research, 23(3), 655-692.

Lin, W., \& Rong, M. (2012). Impacts of Other Comprehensive Income Disclosure on Earnings Management. Nankai Business Review International, 3(1), 93101.

Lobo, G., \& Zhou, J. (2001). Disclosure Quality and Earnings Management. AsiaPacific Journal of Accounting \& Economics, 8.

Lobo, G., \& Zhou, J. (2006). Did Conservatism in Financial Reporting Increase After The Sarbanes Oxley Act? Initial Evidence. Accounting Horizons, 20, 57-73.

Schipper, K. (1989). Commentary on Earnings Management. Accounting Horizons, 3, 91-102.

Subramanyam, K. (1996). The Pricing of Discretionary Accruals. Journal of Accounting and Economics, 22, 248-281. 
Teoh, S., Welch, I., \& Wong, T. (1998). Earnings Management and The Long-Run Market Performance of Initial Public Offering. Journal of Finance, 53.

Watts, R., \& Zimmerman, J. (1978). Towards a Positive Theory of The Determination of Accounting Standards. The Accounting Review, 53, 112134.

Watts, R., \& Zimmerman, J. (1990). Positive Accounting Theory: A Ten Year Perspective. The Accounting Review, 65, 131-156. 